$\begin{gathered}\text { Journal of Business Management and } \\ \text { Economic Research }\end{gathered}$
$\begin{gathered}\text { 2018, 2(10): 39-54 DOI: 10.29226/TR1001.2018.69 } \\ \text { Journal Homepage: https://www.jobmer.org }\end{gathered}$

\title{
Prospect and Development Strategy of MSME Mango Dodol Processing : Case Study at Kameumeut MSME, Cirebon Regency, West Java, Indonesia
}

\author{
Fitri Hidayah Laila Pohan \\ Department Socio economics of Agriculture, Agriculture Faculty, Padjadjaran University, \\ Indonesia, fitrihlp.fhlp@gmail.com
}

\section{Lies Sulistyowati}

Department Socio economics of Agriculture, Agriculture Faculty, Padjadjaran University, Indonesia, lies.sulistyowati@unpad.ac.id

\begin{abstract}
Cirebon Regency is one of mango production centers in West Java Province, Indonesia. The availability of abundant mango in the mango season has resulted in lower mango prices. Mango dodol processing is one of the alternatives to the use of mangoes that are easy to do community. MSME Kameumeut is one of MSMEs (Micro-Small and Medium Enterprises) in the scale of micro business in Cirebon Regency. This study aims to : 1) to describe the effect of dodol mango business, 2) to analyze the prospect of mango dodol processing, and 3) to analyze the development strategy of MSME Kameumeut. The research design is qualitative and used descriptive analysis, difference of raw materials, profit analysis, BEP, R-C ratio, market analysis and SWOT analysis. The results had shown that MSME gave a profit of Rp 2,575,581 per twelve times of production for one month with R-C ratio of 1.39. It meant that MSME Kameumeut was worthy of being cultivated and profitable. The strategy which is the main objective to be applied by MSME Kameumeut is to maintain continuity of product and cooperation with marketer partner.
\end{abstract}

Keywords: Performance, Strategy, MSMEs of Mango Processor, SWOT, QSPM 


\section{Introduction}

The agricultural sector has an important role in the Indonesian economy, especially in the formation of gross domestic product (GDP). GDP distribution according to economic sector or business field based on constant prices shows the role and changes of Indonesia's main economic structure consisting of the manufacturing industry sector, the agricultural sector and the trade sector.

The agricultural sector is divided into the food crop subsector, the horticultural subsector, the forestry sub-sector, the plantation sub-sector, the livestock sub-sector and the fisheries subsector. The horticultural crop sector is one of the agricultural sectors which is one of the largest contributors to the agricultural sector GDP, which is 14.70 percent of the agricultural sector GDP in 2015 (BPS, 2016).

Indonesia's mango harvest area in 2010 to 2014 has increased while production and productivity have fluctuated (Ditjen Horticulture, 2015). Mango harvest area in 2010 amounted to 131,674 ha increased to 268,053 ha in 2014 . The average growth of mango harvest area per year was 21.15 percent. Mango productivity for five years (2010-2014) showed an increase of $1,287,287$ tons, increasing to 2,431,330 tons. Mango productivity for 5 years (2010-2014) shows a decrease of 9.78 tons per hectare to 9.07 tons per hectare. Increased mango production is mostly due to an increase in mango harvest area. The average growth of mango productivity per year is -1.35 percent.

Table 1. Extent of Harvest, Production and Productivity of Mangoes in Indonesia in 20102014

\begin{tabular}{cccc}
\hline \multicolumn{4}{c}{$\mathbf{2 0 1 4}$} \\
\hline Year & Harvest Area (Ha) & Production (Tons) & Productivity (Tons/Ha) \\
2010 & 131.674 & 1.287 .287 & 9,78 \\
2011 & 208.280 & 2.131 .139 & 10,23 \\
2013 & 219.666 & 1.376 .333 & 10,82 \\
2014 & 247.239 & 2.192 .928 & 8,87 \\
Growth Rates per & 268.053 & 2.431 .330 & 9,07 \\
Year (\%) & 21,15 & 25,08 & $-1,35$ \\
\hline
\end{tabular}

Source: Ditjen Hortikultura, 2015

Based on physical potential such as climate land suitability, human resources, and the level of technological adaptation, mango plants can be cultivated in various regions in Indonesia. Mango production data in Indonesia in 2014 shows that there are five provinces which are the largest mango production centers in Indonesia, including East Java, Central Java, West Java, South Sulawesi and West Nusa Tenggara. West Java Province which is equal to $13.22 \%$ (Directorate General of Horticulture, 2015).

Although the national mango production level increases every year, reports on price developments indicate that the selling price of mango in West Java itself still fluctuates sharply due to non-continuous (seasonal) production. When supply is abundant, the selling price of mango falls and even reaches a percentage of almost 86\% (Agriculture Ministry of Indonesia, 2014). This results in the availability of mango dodol processing raw materials related to the price of production inputs.

Cirebon Regency is one of the mango production centers after Indramayu and Majalengka Districts in West Java Province. Mango production in Cirebon Regency in 2015 was 37,443 tons (Table 2). Mango production in Cirebon Regency tends to fluctuate from 2011-2015. 
Journal of Business Management and Economic Research, vol.2, issue.10, pp.39-54

Table 2. Mango production in the Sentra Mangga area of West Java

\begin{tabular}{lccccc}
\hline \multicolumn{5}{c}{ Mango Production in the Central Java Province Mangga Sentra Region (Tons) } \\
\cline { 2 - 6 } \multicolumn{1}{c}{ Location } & 2011 & 2012 & 2013 & 2014 & 2015 \\
& 44868 & 39377 & 32406 & 23329 & 32108 \\
Kuningan Regency & 55981 & $\mathbf{6 2 0 5 3}$ & 30945 & $\mathbf{5 1 6 6 1}$ & 37443 \\
Cirebon Regency & 43280 & 48521 & 10243 & 57172 & 64394 \\
Majalengka Regency & 21169 & 29008 & 23607 & 20633 & 23491 \\
Sumedang Regency & 63057 & 68506 & 84788 & 72436 & 69737 \\
Indramayu Regency &
\end{tabular}

Source: Statistics of Food and Horticulture Plants in 2011-2015

Mangoes in Cirebon Regency are planted in several districts including Astanajapura District. Mango production produced in Cirebon Regency around 20\% is mango reject (Sulistyowati, 2015), which has no value or is valued at very low value. This requires a breakthrough to provide added value by processing mango into processed products, including being mango dodol. Mango processing becomes processed products such as dodol, sweets, juice, and puree. Mango fruit processing aims to extend shelf life and increase sales value.

Micro, small and medium enterprises (MSMEs) are described as sectors that have an important role for economic development in Indonesia, because most of the population lives in small business activities both in traditional and modern sectors. The role of small-scale businesses is a priority part in every planning of development stages. In 2013, there was an increase in the number of MSME units seen in (table 3) when compared to 2012.

Table 3. Development of Small and Medium Enterprises (MSMEs) Data for 2012-2013

\begin{tabular}{rrlrrr}
\hline No & \multicolumn{1}{c}{ Indicator } & Unit & \multicolumn{1}{c}{2012} & \multicolumn{1}{c}{2013} \\
\hline 1 & Business Unit & & & \\
& 1. Micro Business & (unit) & 55.856 .176 & 57.189 .393 \\
& 2. Small Business & (unit) & 629.418 & 654.222 \\
& 3. Medium Business & (unit) & 48.997 & 52.106 \\
& Labor & & & \\
& 1. Micro Business & (orang) & 99.859 .517 & 104.624 .466 \\
& 2. Small Business & (orang) & 4.535 .970 & 5.570 .231 \\
& 3. Medium Business & (orang) & 3.262 .023 & 3.949 .385 \\
& GDP at Current Prices & & & \\
& 1. Micro Business & & & \\
& 2. Small Business & (Rp. Milyar) & $2.951 .120,6$ & $3.326 .564,8$ \\
& 3. Medium Business & (Rp. Milyar) & $798.122,2$ & $876.385,3$ \\
& & (Rp. Milyar) & $1.120 .325,3$ & $1.237 .057,8$ \\
& GDP & at a constant price of & & & \\
& 2000 & & & \\
& 1. Micro Business & (Rp. Milyar) & $790.825,6$ & $807.804,5$ \\
& 2. Small Business & (Rp. Milyar) & $294.260,7$ & $342.579,19$ \\
& 3. Medium Business & (Rp. Milyar) & $366.373,9$ & $386.535,07$ \\
\hline
\end{tabular}

Source : http://www.depkop.go.id

One of the SMEs in Cirebon Regency is processing mango dodol. Mango (Mangifera indica) is one of the tropical and subtropical fruits produced by Indonesia. Usually, it can also be used as a dessert, but can also be consumed through preparations such as mangoes such as dodol, sweets, juices and puree. Mango processing is one of the efforts so that the community can take fruit and benefits by reprocessing mango into processed products. 
The number of MSME mango dodol in Cirebon Regency is 3 units in 2016. The number of MSMEs in the previous year was 5 MSME in 2015. The processing of mango dodol is a fruit processing activity that is relatively easy and can be used in one day. Production process tools used in household processing, activities that can be made by people who do not have a lot of capital.

One of the MSME in Cirebon Regency is Kameumeut MSME. These MSMEs are classified on a micro business scale. Kameumeut MSME is located in Munjul Village, Astanajapura Subdistrict, which was established in 2014. Among the 3 MSME processing mango dodol in Cirebon Regency, Kameumeut MSME is a MSME that produces dodol and product distributors in Cirebon. This study aims to describe the performance and analyze the development strategy of MSME processing of mango dodol in Munjul Village, District Astanajapura, Cirebon Regency.

\section{Method}

This research was conducted at Kameumeut MSME, Munjul Village, Astanajapura District, Cirebon Regency. Site selection was carried out purposively with the consideration that Kameumeut MSME was the only mango dodol processor in Munjul Village, Astanajapura District, Cirebon Regency, as well as sustainable production and established business partners. The research design used was qualitative with the aim of presenting a detailed outlook and development strategy for the processing of mango dodol by Kameumeut MSME in Munjul Village, Astanajapura District, Cirebon Regency.

In this study researchers used case study research techniques. Case studies are one method for understanding individuals who are carried out integratively and comprehensively in order to obtain an in-depth understanding of the individual and the problems he or she faces with the goal of the problem being resolved and gaining good self-development (Susilo Rahardjo \& Gudnanto, 2011).

\section{1) Descriptive Analysis}

Descriptive analysis is an analysis that is useful to describe the variables studied (Arikunto, 2002). This analysis is used as a tool to find out and explain the general description and availability of mango dodol processing supporting material in the study area which was analyzed descriptively.

2) Profit Analysis

The benefits of MSME processing of mango dodol can be analyzed using the following formula:

$$
\pi=\mathrm{TR}-\mathrm{TC}
$$

Infromation: $\begin{array}{ll}\pi & =\text { Business benefits of mango dodol (Rp.) } \\ \text { TR } & =\text { Total Revenue (total revenue) mango dodol (Rp) } \\ \text { TC } & =\text { Total Cost (Total Cost) of mango dodol (Rp) }\end{array}$

3) BEP analysis

Break Event Point (BEP) is a state or sale of business where the amount of benefits (income) is equal to expenditure (cost) in other words in this situation the company does not get profit or loss (Fatah, 1994).

BEP Production $\quad=$ TFC $/(\mathrm{P}-\mathrm{AVC})$

BEP Price $\quad=$ TFC $/(1-(A V C / P))$

Information :

TFC $=$ Total Fixed Cost (Total Fixed Cost) 
$\mathrm{P} \quad=$ Price

AVC = Average Variable Cost / unit

A business activity is feasible if the benefits are greater than the sacrifice (cost). According to Soekartawi (2002), the analysis of return cost ratio is a comparison between revenues and costs. The revenue ratio of production costs can be used to measure the level of relative profit of a business, meaning that the figure of the ratio of revenue to costs can be known whether a business is profitable or not. Mathematically can be formulated as follows:

$$
\mathrm{R} / \mathrm{C} \text { - of Total Cost }=\mathrm{TR} / \mathrm{TC}
$$

Information:

$$
\begin{aligned}
& \text { TR }=\text { Total Revenue } / \text { Total Revenue }(\mathrm{Rp}) \\
& \mathrm{TC}=\text { Total Cost } / \text { Total Cost }(\mathrm{Rp})
\end{aligned}
$$

4) SWOT analysis

This analysis is based on logic that can maximize strengths and opportunities (Opputunities), but simultaneously can minimize weaknesses (Weakness) and threats (Threats) (Rangkuti, 2007). According to Situmorang and Dilham (2007) in making a SWOT analysis steps can be taken as follows:

1. Preparation: equalize understanding (perception)

2. Identifying internal factors and external factors

3. Creating an Internal Evaluation Matrix (EFI) and External Factor Evaluation (EFE)

4. Creating MSME Position Matrices

5. I-E matrix

\section{5) Quantitative Strategic Planning Matrix (QSPM)}

Quantitative Strategic Planning Matrix is an analytical technique designed to establish the relative appeal of appropriate alternative actions by ranking strategies for obtaining a priority list. QSPM is a tool that allows strategists to evaluate alternative strategies objectively, based on critical factors for previously recognized external and internal success. Alternative strategies are obtained from the analysis of I-E matrix and SWOT matrix.

\section{Results and Discussion}

Kameumeut dodol business is one of the micro-scale household industry that produces dodol products and has P-IRT (Household Industry Food) licenses in Munjul Village, Astanajapura District, Cirebon Regency. Micro business is said if a business has an asset value of at most Rp.50,000,000 and the number of permanent workers is up to 4 people. This business is a business that is engaged in the processing of special souvenirs from Cirebon made from mango gedong. The result of processing the mango is a product called mango dodol gedong Kameumeut.

This initial capital is a private capital that is considered sufficient because the dodol processing is still simple. At first the tools used for the production process are household kitchen appliances that are used daily. The recipe for processing this product is the result of personal learning by the owner. 


\section{Performance of Kameuemeut MSME}

A. Production Factor

a. Capital

Capital is one of the important factors in establishing a business, without sufficient capital, the business built will not run as it should. The amount of initial capital used is Rp. 1,000,000 to carry out the initial process of production. The source of capital used by Kameumeut MSME comes from the personal savings of business owners.

Capital limitations are a weakness in this business. The capital of MSMEs is still limited to their own capital. The owner increases his capital by saving from the profits obtained from the sale for business development in increasing the scale of production. The obstacle in obtaining capital is the existence of collateral that must be fulfilled and the inability of the owner to fulfill the loan interest installments.

b. Labor

Workers are workers who are employed to carry out activities in the production process to transform production factors into goods and services to meet the needs of the community. Workers in Kameumeut MSMEs come from the area around Munjul Village. The number of workers owned by business owners is 5 people. All workers owned are female with an age range of 18-40 years. The following is the workforce data in Kameumeut's MSME.

c. Raw Materials and Supporting Materials

The raw material used is mango gedong which is still suitable for consumption on condition that it does not rot and is not exposed to fruit flies. For one time mango dodol production was used as much as $12 \mathrm{~kg}$ of gedong mangoes. This raw material is obtained from the produce of the business owners and farmers around Munjul Village. Mango is one of the seasonal fruits, so to obtain the continuity of the availability of raw materials, storage of fruit meat in the freezer is stored which can last for 1 year. In addition, to meet the needs of raw materials by looking to other areas such as Indramayu Regency and Majalengka Regency.

Supporting materials used are sugar, brown sugar, sticky rice flour, coconut milk, gelatin, salt and citrun. For one time the production of dodol mango gedong used $3 \mathrm{~kg}$ of sugar, $1.5 \mathrm{~kg}$ of sticky rice flour, 3 packs of coconut milk, 2 packs of gelatin, salt and sufficient citrun. Supporting materials used were obtained from the Cipeujeuh Market in Munjul Village. Owners usually buy supporting materials once a week.

\section{d. Technology}

The equipment used by Kameumeut MSME in dodol processing is said to be simple, because the use of these tools can be found in Indonesian household appliances. The Directorate of Agricultural Product Processing does not specifically apply the Standard Operating Procedure (SOP) in processing mango dodol, so the owner has an SOP set by the internal MSME.

B. Production process

The process of making gedong mango dodol is divided into three processes, namely mango washing and stripping process, processing, and packaging.

C. Marketing

The marketing area of mango gedong dodol produced by Kameumeut MSME is mostly in Cirebon Regency and some are sold outside the region such as Tegal and Bandung. The 
marketing area of mango dodol in Cirebon Regency includes sales in several souvenir shops such as Batik Trusmi, Adi Joy Stores, Daud Stores, Ade Stores, Johan Stores, and Aneka Kue Stores.

The MSME way Kameumeut promoted his products through exhibitions held by several institutions (such as BI, the Industry and Trade Office), products made into special products of several institutions for meetings, social media (such as Facebook and Instagram) and dodol mango gedong Kaemeumeut can be obtained online through Tokopedia. The owner also sells directly to consumers at home.

The marketing channels that have been carried out by Kameumeut MSME in Cirebon Regency

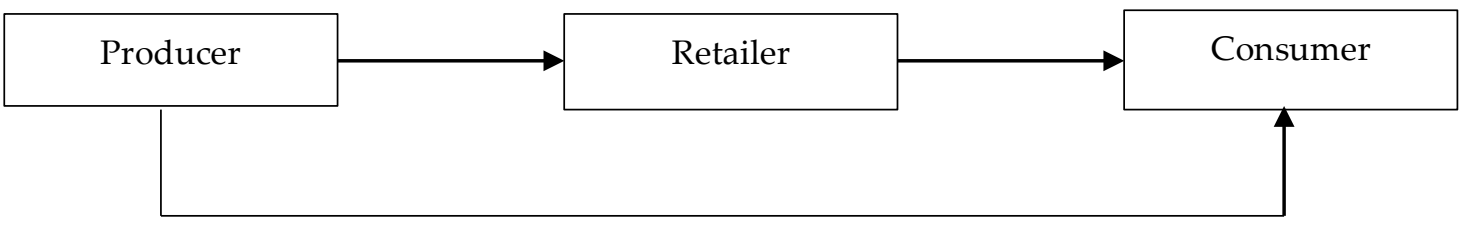

Figure 1. Marketing Channel of Gedong Kameumeut Mangga Dodol

2. Prospects of Mango Dodol Processing Business of Kameumeut MSME

A. Availability of Raw Materials

The main raw material in making mango dodol is mango gedong. According to data from the Cirebon District Agriculture Office (2017) the amount of mango production in Cirebon Regency is $30,227.4$ tons per year, while the mango needs to produce dodol as much as $12 \mathrm{~kg} / 1 \mathrm{time}$ production or as much as $1,728 \mathrm{~kg}$ / year, so that mango needs can be met.

Mangoes used as raw material for making dodol mango do not really need the best criteria, the main requirement is not rotten and not affected by fruit flies. To meet the availability of raw materials. From reject mangoes from supermarkets as much as $65 \%$ and the rest is obtained from the market in Munjul and mango apabalia is not season so it is obtained from areas around Cirebon. In addition, to meet the needs of raw materials, mango during the harvest season will be stored in a freezer that can last for one year by giving mango treatment in the form of mango washing and mango stripping.

B. Analysis of Total Costs, Receipts and Profits

The total cost of Kameumeut MSME issued each month is derived from the sum of fixed costs and variable costs. The total cost spent by Kameumeut's MSME for one month for 12 production processes can be seen in Table 4 .

Table 4. Total Cost of Kameumeut MSMEs (1 Month)

\begin{tabular}{llrr}
\hline No & \multicolumn{1}{c}{ Jenis Biaya } & Total Cost(Rp) & Percentage (\%) \\
\hline 1. & Fixed Cost & 854.194 & 12,82 \\
2. & Variable Cost & 5.810 .225 & 87,18 \\
\hline & Total Cost & 6.664 .419 & 100,00 \\
\hline
\end{tabular}

Source: Data Processed, 2018

Table 4 shows that the total costs incurred for one month amounted to Rp $6,664,419$. The biggest percentage is the variable cost, which is $87.18 \%$, while the fixed cost is $12.82 \%$. This condition is caused by the type of variable costs that are more than the fixed costs, so that the costs incurred to meet production needs are greater. The biggest cost incurred is the cost for 
labor wages of $30.61 \%$ of the total costs incurred with the smallest cost is the cost of rent in the fixed cost component.

The revenue received by Kameumeut MSMEs from one month of mango dodol processing business was Rp. 9,240,000 which was obtained from the product quantity of 660 packs at a price of Rp. 14,000 / pack. Such receipts are classified as gross receipts, so that to receive net profits it is necessary to reduce the total costs incurred for the production process. calculation of profits can be seen in table 5 .

Table 5. Kameumeut MSME Profit Calculation (1 Month)

\begin{tabular}{lr}
\hline \multicolumn{1}{c}{ Uraian } & \\
\hline Revenue & Jumlah \\
Total Cost & $\operatorname{Rp~} 9.240 .000$ \\
Profit & $\operatorname{Rp} 6.664 .419$ \\
R-C Ratio & $\operatorname{Rp~} 2.575 .581$ \\
$B E P$ price & 1,39 \\
$B E P$ production & $\operatorname{Rp~2.308.632}$ \\
\hline
\end{tabular}

Source: Data Processed, 2018

Table 5 shows that the benefits obtained by Kameumeut MSMEs amounted to Rp 2,575,581 in the period of one month. This business feasibility ratio is 1.39. According to Soekartawi et al. (2002), the business is said to be feasible and profitable if the R-C ratio is greater than 1 . This means that the dodol mango gedong product produced by Kameumeut MSMEs is worthy of effort. Profits can be obtained if production results and selling prices exceed the breakeven price point (BEP price) and production break-even point (production BEP). Based on calculations from the data obtained, Kameumeut's MSMEs exceeded the break-even point, namely for the break-even point of revenue of $\operatorname{Rp} 2,308,632$ and a break-even point of 164 packs.

C. Market Analysis

One of the applications of the marketing concept is an understanding of the needs, desires and behavior of customers. For this reason, a business must be able and willing to listen to the customer's voice through market analysis. Limited time, opportunities and data to analyze Kameumeut's MSMEs directly to consumers, the authors attempt to describe it in general. This can be seen from the sales volume, the number of stores for dodol distribution, the influence of regional development, and the location of the production area. 


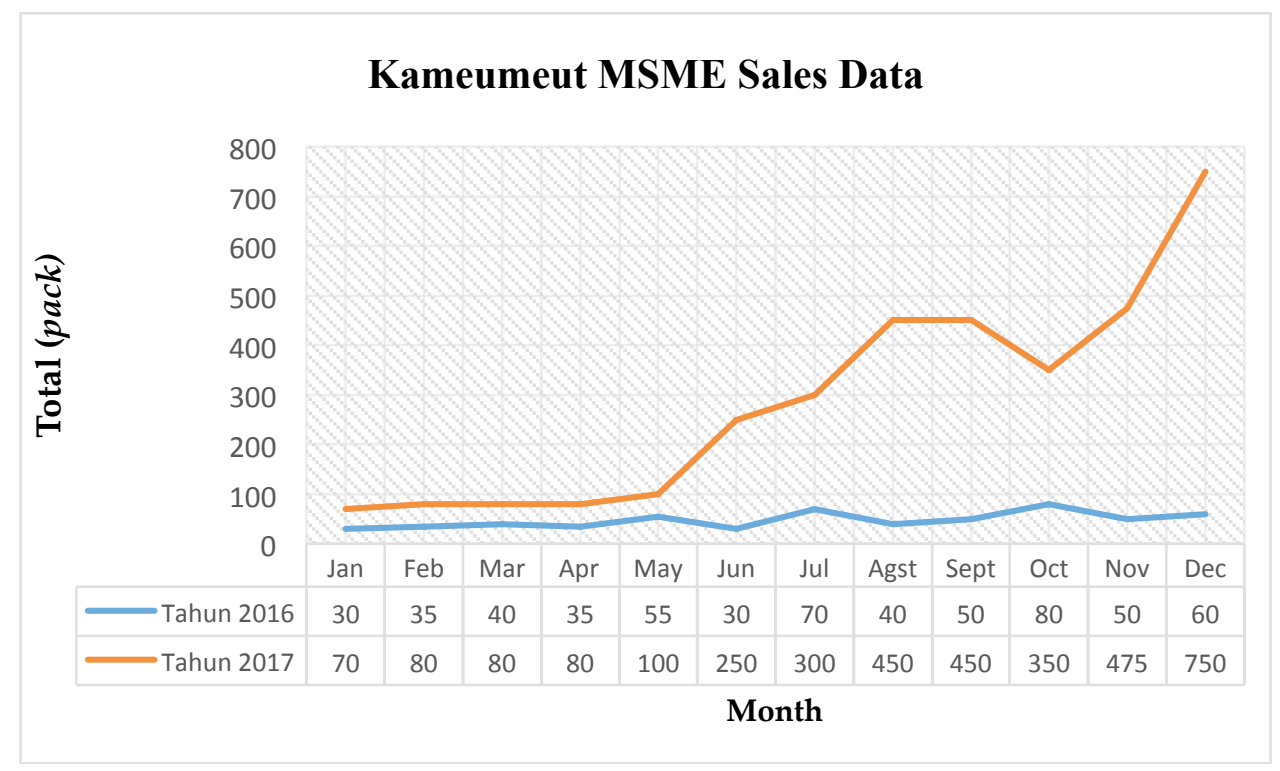

Figure 2. Kameumeut MSME Sales Data

According to Schiffman (2004), sales volume is the level of sales obtained by the company for a certain period in units (units / total / rupiah). According to Basu Swasta (2004), sales is an interaction between individuals face to face aimed at creating, improving, mastering or maintaining an exchange relationship so that it is beneficial for others. Sales of mango dodol in Kameumeut MSMEs in 2016 and 2017 tend to increase every month. Sales continue to increase from January 2016 to December 2017. In 2016, the total sales volume was 575 packs and in 2017 increased to 3435 packages. The percentage of sales increase is $497.40 \%$. Sales increase usually occurs in July and December. This is due to the Eid holiday, school and year end. The volume of increased sales increased due to requests from souvenir shops in Cirebon, so that the owners increased the scale of production. In addition the owners also participated in exhibitions in several cities (such as Cirebon, Bandung, Pontianak, Bogor, Tangerang and Garut) held by the government.

The shop partner who markets dodol MSME Kameumeut is a gift shop in Cirebon. At the beginning of the establishment of this business, stores that partnered with Kameumeut MSME were as many as 2 stores. In 2017 increased to 8 stores.

Demodal demand will increase due to the increase in the number of tourists to Cirebon. Cirebon is projected to get tourist visits of up to 1 million in 2018. The operation of the West Java International Airport is one of the supporting factors for achieving the target. Another supporting factor is the presence of the Cikopo-Palimanan toll road. In addition, the attraction of tourist visits to Cirebon is culinary tourism, shopping and historical tourism. The increasing number of tourists will increase the visit to souvenir shops in Cirebon and is a market opportunity for MSMEs to develop their products.

3. Analysis of the Internal and External Environment of Kameumeut MSME

A. Internal environment

a. Human Resources

Workers who work in Kameumeut MSME come from the neighborhood around Munjul Village, totaling 5 people. All of these workers are women, this is in line with the aim of the owner to help women around the business environment in getting a job so that they are not unemployed. 
The length of time worked at Kameumeut MSME is around 8 hours, from 07.00-12.00 then rest and restart at 13.00-16.00.

Interaction between workers in the Kameumeut MSMEs looks very good and family-friendly because of the same regions and tribes. The relationship between owner and worker is very close but does not interfere with the running of the existing work system. To improve the ability of the workforce to support the production process, the government does not provide special training for the manufacture of mango dodol. So that the owner only depends on selfdevelopment through the internet and business experience.

For dodol processing, it takes 2 workers and 3 people for dodol packaging. Distribution of wages for workers is determined based on the division of labor, namely Rp. 40,000 for the cooking process and Rp. 30,000 for workers who carry out packaging and usually the wages are given after performing their respective duties. In addition to the wages earned, workers also get lunch from business owners.

\section{b. Production}

Production and operation activities have not run effectively and efficiently. This can be seen in the use of tools in the manual production process. The treatment process is one of the processes that has a long time in the stirring part of the dough which takes about 6 hours. This has an effect on the work pattern of workers in production activities the next day because they complain that the hands are not strong anymore. The time needed for mango processing is 7 hours and for 6 hours packaging. Before packaging, dodol requires cooling time in open spaces for 1 night.

The place for production activities is still incorporated into the house of the owner. Usually the production process is carried out in front of the owner's house. This certainly affects the cleanliness of the product because the location is right on the edge of a public road and there is no special equipment used by workers. In addition, the position of the production site that is still not permanent makes the production preparation process require more time to prepare the tools and materials.

Mango quantity every time the production process is as much as $12 \mathrm{~kg}$ which will produce the final yield of 55 packs weighing 200 grams each. The production process is 12 times each month, so it takes $144 \mathrm{~kg}$ mango with not too good quality mangoes. The requirements for mangoes used for dodol processing are not rotten and not affected by fruit flies. Production techniques carried out for processing mango dodol are still relatively simple. The tools needed can be found in every kitchen of Indonesian family households. One of the tools that uses a machine is only a fruit crusher, namely a blender. But if this tool is not available, mangoes only require slicing manually using a knife.

c. Marketing

Kameumeut MSMEs have one type of mango processed product which is dodol. The product is packaged in a special green cardboard packaging. Kameumeut MSME uses the brand "Dodo Mangga Gedong Kameumeut". The price of mango dodol offered is IDR 14,000 and weighs 200 grams. The packaging has included the product identity in the form of product name, composition, product expiration date, weight of contents, halal label of MUI (MUI. JB. 01191169400616), permission of P-IRT (Din. Kes. P-IRT No. 2063209011 073) can be seen in Figure.

The production location of gedong mango dodol is in the owner's house, Eti Rohaeti, which is precisely on Jalan Raya Munjul, RT 03 / RW 03, Munjul Village, Astanajapura District, Cirebon 
Regency. Mango Dodol can be purchased directly to the production site. In addition to marketing directly, Kameumeut MSMEs also market to several partner shops around Cirebon such as Batik Trusmi, Adi Joy Stores, Daud Stores, Ade Stores, Johan Stores and Aneka Kue. Distribution of goods is carried out by delivering directly to the marketer's partner shop by the owner.

The payment system that is carried out is to pay directly and leave a purchase note that has not been paid. In addition to marketing in Cirebon, the owner has also tried to expand the coverage of marketing by marketing products to Tegal and Cihampelas, Bandung. Product promotion is also carried out by Kameumeut MSMEs. This is done by participating in exhibitions conducted by the government (Trade Office and MSME Office) and BI. In addition, Kameumeut's MSMEs also market their products to government agencies when conducting meetings so that they can simultaneously promote products outside the region. Promotion is also done through the use of social media, namely Instagram and Facebook. This product can also be obtained online through Bukalapak's purchasing network. The difficulty experienced by Kameumeut MSMEs in marketing their products outside the Cirebon area is the amount of transportation costs, so that the owners handle them by utilizing their free time when going to Bandung or Tegal.

\section{d. Finance}

In running a business, capital problems are very important. Mango processing in Cirebon Regency has long been carried out by the community for generations. At first Kameumeut MSME started a business with a relatively small capital, where business capital was spent on its own. The initial capital in establishing a business is Rp. 1,000,000. The capital used for the production process is relatively small and limited. There are three ways of obtaining capital, namely capital, family loans and bank loans. The owner prioritizes own capital and loans to the family. The owner saves money from profits from the business to increase business scale. Administrative systems such as bookkeeping have not been carried out routinely by Kameumeut MSMEs either weekly or monthly. The owner sometimes still mixes personal money with business money because there is no systemized administration.

Kameumeut MSMEs have the desire to buy automatic dodol stirrers, but they cannot be achieved due to limited capital. The owner has submitted a proposal for submission of assistance funds to several government agencies such as Disperindag and the MSME Cooperative Office, but has not yet materialized until now. For borrowing capital from the bank, the owner does not have a desire because of the limited ability to pay interest on the loan and the process of the requirements are not met. The method used by MSME owners to be able to buy the equipment needed is by saving profit.

e. Technology

The technology used by Kameumeut MSMEs in supporting the production process is still relatively simple. The equipment used is still done manually. The production process is long enough to process dodol so that sometimes more work is needed to carry out the stirring process. The owner has planned to switch from manual stirring to automatic stirrer, but this cannot be done because it is limited by capital.

\section{B. External environment}

\section{a. Supplier}

Suppliers are parties who provide input needs in the production process, namely raw material in the form of mango gedong. The raw materials needed by Kameumeut MSME are obtained from the owner's and mango reject gardens which are rejected from modern retailers. The 
mangoes are obtained from mango suppliers to modern retailers and exporters who are the husbands of these business owners. If there is no mango from the two sources, then the owner buys mango from around Cirebon or outside the area such as Indramayu and Majalengka Regencies. Pricing is based on an agreement with the mango supplier that applies at that time. If the mango is in a harvest season, the owner will buy a larger amount of raw material so that it can be stored in the freezer and can be used when mango is not seasoned. The average price for purchasing raw materials is IDR 10,000. purchases are made in cash to mango suppliers.

\section{b. Partnership}

Kameumeut MSMEs have collaboration with several souvenir shops in Cirebon, including Batik Trusmi, Adi Joy Stores, Daud Stores, Ade Stores, Johan Stores, and Aneka Kue. The partnership that is carried out opens the opportunity for increased demand for this mango dodol product. But other than that, working with several partners will cause problems such as the failure to fulfill the requests of all parties due to the lack of production capacity in Kameumeut MSMEs. Each partner has a different system for collaborating. Partnership agreements in the form of written contracts have not all been implemented, but the cooperation contract with Batik Trusmi has been carried out.

c. Competitor

Kameumeut MSME competitors come from dodol processors around Cirebon. For this business there is no great competition between dodol processors in Cirebon. The process of processing mango dodol which is quite easy and simple is one of the factors that causes competition in processing mango. In Cirebon District, in 2017 there were only three mango dodol processors and Kameumet MSMEs were the largest and most sustainable business scale processors. Other processors do not develop because they are limited to the availability of seasonal mango and low product quality, so they only produce mango at certain times and only market around the production site. Products produced by competitors have not been able to partner with souvenir shops in Cirebon because they have not met the existing sales standards, such as packaging there are no trademarks, date of registration, etc. When compared to Kameumeut's MSMEs, competing products can only last for 1 week and will be moldy. Unlike the case with Kameumeut MSME, the quality of its products is able to compete and be accepted by the market.

Besides competitors from Cirebon, the main competitor of Kameumeut MSME came from outside Cirebon, namely dodol mango from Indramayu Regency. Mango Dodol competitors have begun to enter souvenir shops in Cirebon such as Ade shop. The product that is a competitor of Kameumeut's MSME dodol is mango dodol Ibu Kasturi. The price offered by Ibu Kasturi's dodol mango is higher compared to Kameumeut's MSME mango dodol with a price difference of IDR 2,500 and the same weight. The packaging design that is owned by dodol mango Ibu Kasturi is similar to the packaging of Kameumeut's MSME mango dodol.

Product innovation was also carried out by Kameumeut MSME competitors. One such innovation is chocolate filled with mango dodol. In addition to the old processors of mango dodol, the arrival of newcomers will be a threat to Kameumeut's MSME. With the increase of tourists from outside the area to Cirebon can lead to the emergence of new entrepreneurs will increase. This is a threat to Kameumeut's MSMEs because it will affect product sales.

\section{Internal-External Matrix Analysis (I-E)}

Based on the results of the IFAS and EFAS matrix, the IFAS total score is 2.774 which shows that the internal conditions of Kameumeut's MSME are in the average position and the EFAS total 
score is 2.544 which indicates the external condition is in the middle or medium position. From these results it can be seen that Kameumeut MSME is in cell V in the IE matrix.

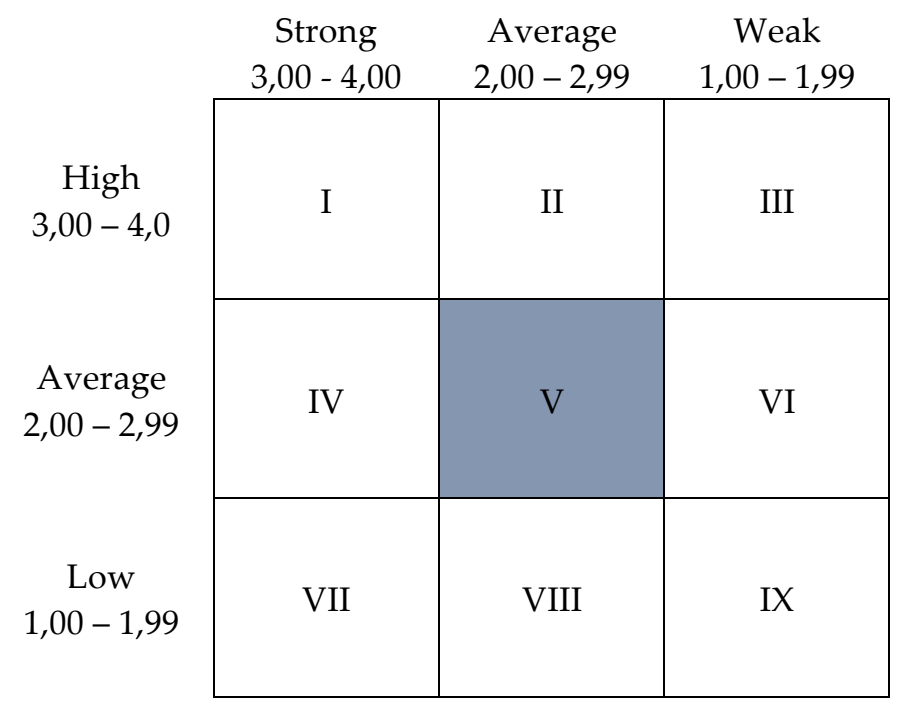

Figure 3. Kameumeut MSME IE Matrix

Source: Primary Processed Data, 2018

The IE diagram at position V shows that Kameumeut's MSME development is in a position of maintaining and maintaining. According to David (2003), the strategy used in this position is market penetration and product development. This strategy can be done in several ways such as the development of product innovations such as flavors, shapes and sizes, and increasing the scope of marketing at a broader stage.

5. Quantitative Strategic Planning Matrix (QSPM) Analysis

QSP matrix analysis is used to determine the priority strategies that can be taken for the development of Kameumeut MSMEs. The following alternative strategy results from the calculation of the QSPM matrix based on the total order of the highest to lowest attraction.

Table 6. Kameumeut MSME QSPM

\begin{tabular}{|c|c|c|c|}
\hline No & $\begin{array}{l}\text { Name of } \\
\text { Strategy }\end{array}$ & Strategy & $\begin{array}{c}\text { Total of } \\
\text { Attractiveness Score } \\
\text { (TAS) }\end{array}$ \\
\hline 1. & SO1 & $\begin{array}{l}\text { Maintaining product continuity so as to maintain } \\
\text { the stability of cooperation with dodol product } \\
\text { marketing partners }\end{array}$ & 5,47 \\
\hline 2. & $\mathrm{SO} 4$ & $\begin{array}{l}\text { Increase the scale of dodol production to support } \\
\text { the empowerment of women around the } \\
\text { Kameumeut MSME location. }\end{array}$ & 5,40 \\
\hline 3. & $\mathrm{SO} 2$ & Expand the marketing range of dodol products & 5,26 \\
\hline 4. & $\mathrm{SO} 3$ & $\begin{array}{l}\text { Utilizing the support of government policies to } \\
\text { expand the market }\end{array}$ & 5,14 \\
\hline 5. & WT2 & $\begin{array}{l}\text { Optimizing the use of technology to increase the } \\
\text { shelf life of raw materials. }\end{array}$ & 5,04 \\
\hline 6. & WO1 & $\begin{array}{l}\text { Empowerment of financial institutions and training } \\
\text { in the use of effective capital for developing regional } \\
\text { MSMEs. }\end{array}$ & 4,66 \\
\hline 7. & ST1 & Establish and maintain relationships with marketers & 4,51 \\
\hline
\end{tabular}


Journal of Business Management and Economic Research, vol.2, issue.10, pp.39-54

\begin{tabular}{cclc}
\hline No & $\begin{array}{l}\text { Name of } \\
\text { Strategy }\end{array}$ & \multicolumn{1}{c}{ Strategy } & $\begin{array}{c}\text { Total of } \\
\text { Attractiveness Score } \\
\text { (TAS) }\end{array}$ \\
\hline 8. & WO2 & $\begin{array}{l}\text { so that products can be stable on the market } \\
\text { Follow activities held by the government to } \\
\text { promote products. } \\
\text { Buy large quantities of raw materials to overcome } \\
\text { shortages when the fruit is not seasoned } \\
\text { Increased business capital through government } \\
\text { support by holding capital institutions that are } \\
\text { friendly to MSME actors and promoting counseling } \\
\text { on business management. }\end{array}$ & 4,30 \\
\hline & ST2 $\quad$ WT1 & 4,77 \\
\hline
\end{tabular}

Source: Primary Processed Data, 2018

Based on the results of the QSP matrix calculation, the priority strategy is to maintain product continuity so as to maintain the stability of cooperation with dodol product marketing partners (SO1) with a total attraction value of 5.47, while the strategy that gets the lowest total attraction value is 3,77 is an increase in business capital through government support by holding capital institutions that are friendly to MSME players and promoting counseling on business management (WT1).

The first priority strategy relates to market penetration, product development and market development. This is also consistent with the results of the IE matrix which shows that the most suitable strategy for Kameumeut MSMEs is V hold and maintain cells that are related to diversification efforts and do not change the direction of the established strategy. The sustainability of products on the market greatly affects the existence of MSMEs, because if the product is empty on the market, consumers will move to other products. This is related to consumer loyalty to products. This strategy supports the stability of products on the market to get a stable position in the eyes of consumers.

\section{Conclusion}

Based on the discussion of research results, it can be concluded as follows: This business performance is still simple with a micro business scale, limited capital and simple technology. The business prospect of Dodol Mango has a better development, it can be seen in the increase in sales volume. The right development strategy for implementing Kameumeut MSMEs is a type of "hold and maintain" strategy. This strategy can be carried out by maintaining the sustainability of products on the market in order to generate customer loyalty and marketer partners. Kameumeut MSMEs must also begin to innovate with the products produced. 
Journal of Business Management and Economic Research, vol.2, issue.10, pp.39-54

\section{References}

Aditiawati, P., Dea, Indriani., \& Gede, S. (2016, April). Pengembangan Potensi Lokal di Desa Panawangan sebagai Model Desa Vokasi dalam Pemberdayaan Masyarakat dan Peningkatan Ketahanan Pangan Nasional. Jurnal Sosioteknologi.15 (1). Retrieved from: http://journals.itb.ac.id/index.php/sostek/article/view/2041/1169

Anggaraeni, R. (2012). Analisis Pendapatan, Keuntungan dan Kelayakan Usaha Jamur Tiram di Kabupaten Sleman. Journal of Agro UPY.1. p 42-54. Retrieved from: http://repository.upy.ac.id/809/1/Vol\%204\%281\%29-1.pdf

Anitasari, S. Ryo, F. \& Julian, A. (2014). Manajemen Rantai Pasokan Produk Olahan Mangga Arum Manis di Kabupaten Sitibondo. Jurnal Berkala Ilmiah Pertanian. 15. p 1-9. Retrieved from: http://repository.unej.ac.id/handle/123456789/69536

Arikunto, S. (2002). Manajemen Penelitian. Jakarta: Rieneka Cipta.

Badan Pusat Statistik (BPS) Provinsi Jawa Barat. (2016). Jawa Barat Dalam Angka. Bandung: BPS Provinsi Jawa Barat.

Badan Pusat Statistik (BPS). (2016). Laporan Bulanan Data Sosial Ekonomi. Edisi ke-3, Agustus 2016. Jakarta: Badan Pusat Statistik.

Basu, S. \& Irawan. (2002). Manajemen Pemasaran Modren. Edisi Keempat. Jakarta: Penerbit Liberty.

BPS Provinsi Jawa Barat (2016). Jawa Barat Dalam Angka 2013. Badan Pusat Statistik Provinsi Jawa Barat.

David \& Thomas, L. Wheelen. (2003). Manajemen Strategis. Yoyakarta: Penerbit Andi.

Didu, M. (2003, April). Kinerja Agroindustri Indonesia. Agromedia. 8(2). Retrieved from: https://repository.ipb.ac.id/bitstream/handle/123456789/29155/AGR030802msd_2003No2_ 16-25.pdf;jsessionid=B0A822A598F6C94B5E82F58C3E240B4F?sequence $=1$

Dinas Perindustrian. (2007). Standar Nasional Indonesia, Poduk Dodol. Retrieved from: http://www.google.co.id/amp/s/dokumen.tips/amp/documents/sni-dodol.html/ [10/11/2017]

Duan, H., Han, X., \& Yang, H. (2009). An Analysis of Causes for SMEs Financing Difficulty. 4(6), p73-75. Retrieved from: http://citeseerx.ist.psu.edu/viewdoc/download?doi=10.1.1.653.9072\&rep=rep1\&type=pdf.

Fatoni K., Muhammad. (2013). Strategi Pengembanga Buah-Buahan di Jawa Timur. Jurnal Ilmiah Inovasi. 13(1). $\quad \mathrm{p}$ 87-98. Retrieved from: https://publikasi.polije.ac.id/index.php/jii/article/view/115

Khairani, C. \& Dalapati, A. (2007). Pengolahan Buah-buahan. Balai Pengkajian Teknologi Pertanian (BPTP). Sulawesi Tengah.

Kotler, P. (2000). Manajemen Pemasaran. Edisi millenium. (Alih Bahasa: Drs. Benjamin Molan). Jakarta: Prenhallindo.

Mustofa. (2015). IьM Kelompok Usaha Dodol Mangga di Desa Satreyan, Kecamatan Maron Kabupaten Probolinggo. Jurnal Ekonomi, Sekolah Tinggi Ilmu Ekonomi Mandala. 10(3). p 43-45. 
Journal of Business Management and Economic Research, vol.2, issue.10, pp.39-54

Muzhar, M. (1994). Pengembangan Agroindustri dan Berbagai Permasalahannya. Jakarta : Berita Ilmu Pengetahuan dan Teknologi. Tahun Ke-38. No.1.

Novia, Cahyani. (2015). “Diversifikasi Mangga Off Grade Menjadi Selai dan Dodol." Journal of Food Technology, Vol. 6, No. 2, p.55-69. Retrieved from: http://jurnal.yudharta.ac.id/v2/index.php/Teknologi-Pangan/article/view/471

Oktavianto, Yoga. Sunaryo dan Agus Suryanto. 2015. “Karakteristik Tanaman Mangga (Mangifera indica L.) Cantek, Ireng, Empok, Jempol, di Desa Tiron, Kecamatan Banyakan Kabupaten Kediri." Jurnal Produksi Tanaman, Volume 3, Nomor 2, Hal. 91-97.

Pearce, John A. Dan Robinson Richard B. Jr. (2008). Manajemen Strategis 10. Jakarta: Salemba Empat.

Pracaya. (2011). Bertanam Mangga. Jakarta: Penebar Swadaya.

Rahardjo, Susilo dan Gudnanto. 2011. Pemahaman Indiividu Taknik Non Tes. Kudus: Nora Media Enterprise.

Rangkuti, Freddy. (2000). Analisis SWOT : Teknik Membedah Kasus Bisnis. Jakarta: PT Gramedia Pustaka Utama.

Rismunandar. 1986. Mengenal Tanaman Buah - buahan. Bandung: Penerbit Sinar Baru.

Robert, M. Grant. 1997. Analisis Strategi Kontemporer, Konsep, Teknik, Aplikasi. Jakarta: Penerbit Erlangga.

Rohmah, F. (2014). Strategi Pemerintah Daerah dalam Pemberdayaan Usaha Mikro Kecil Menengah Olahan Mangga. Journal of Public Administration. 3(12), p. 25-48. Retrieved fom:

http://administrasipublik.studentjournal.ub.ac.id/index.php/jap/article/view/1090/433

Rukmana, R. (1997). Mangga: Budidaya dan Pascapanen. Yogyakarta : Kanisius.

Schiffman dan Kanuk. (2004). Perilaku Konsumen . Edisi 7. Jakarta: Prentice Hall.

Soekartawi. (2002) Prinsip Dasar Ekonomi Pertanian. Jakarta: Raja Grafindo Persada.

Sulistyowati, Lies. (2015). Pengembangan UKM Pengolahan Mangga Melalui Kemitraan Usaha. Prosiding Seminar Nasional $4^{\text {th }}$ UNS SME's Summit \& Awards 2015. Retrieved from: http://pustaka.unpad.ac.id/wp-content/uploads/2016/06/Abstrak-Pengembangan-UKMPengolahan-Mangga-Melalui-Kemitraan-Usaha_1.pdf

Suyono \& Budiman. (2010). Ilmu Kesehatan Masyarakat. Jakarta: EGC.

Tafajani, D. S. (2011). Panduan Komplit Bertanam Sayur dan Buah-Buahan. Yogyakarta: Cahay Atma.

Umar, H. (2002). Studi Kelayakan Bisnis Teknik Menganalisis Kelayakan Rencana Bisnis Secara Komprehensif. Edisi dua. Jakarta: PT Gramedia Pustaka Utama.

Wahyudi, Agustinus Sri. (1996). Manajemen Strategis: Pengantar Proses Berfikir Strategis. Jakarta: Binarupa Aksara. 